\title{
Dark bronchus sign: a subtle indication of diffuse alveolar haemorrhage
}

\author{
Irfan Ismail Ayub, ${ }^{\oplus 1}$ Natraj Manimaran, ${ }^{1}$ Sandhya Sundaram ${ }^{2}$
}

${ }^{1}$ Department of Pulmonary Medicine, Sri Ramachandra University, Chennai, Tamil Nadu, India

${ }^{2}$ Department of Pathology, Sri Ramachandra University, Chennai, Tamil Nadu, India

\section{Correspondence to} Dr Irfan Ismail Ayub, iia@rediffmail.com

Accepted 17 June 2019 (c) BMJ Publishing Group Limited 2019. No commercial re-use. See rights and permissions. Published by BMJ.

\begin{tabular}{l}
\hline To cite: Ayub II, \\
Manimaran N, \\
Sundaram S. BMJ Case \\
Rep 2019;12:e230991. \\
doi:10.1136/bcr-2019- \\
230991 \\
\hline
\end{tabular}

\section{DESCRIPTION}

A 23-year-old woman presented with history of non-productive cough of 1-month duration. She was diagnosed with systemic lupus erythematosus 2 years ago but discontinued treatment over a year ago. There was no history of haemoptysis, dyspnoea, wheeze, chest pain, fever, joint pain or loss of weight. Clinical examination revealed a malar rash, a respiratory rate of 18 breaths/min with normal cardiorespiratory systemic examination. Other vitals and systems examination were normal.

Blood investigations were normal. Chest X-ray posteroanterior view showed bilateral lower zone haziness. CT scan of thorax showed normal parenchymal architecture. However, on close observation, an overall diffuse and uniform ground glass attenuation of the entire lung parenchyma was discernible on comparing with the dark appearance of the intrabronchial air (figure 1). There was no architectural distortion and no evidence of pleural or mediastinal disease. Two-dimensional echocardiography was normal.

Flexible video bronchoscopy revealed small necrotic nodules overlying posterior and right lateral wall of distal trachea, biopsy of which revealed neutrophilic infiltration of subepithelial vessels with fibrinoid necrosis, suggestive of vasculitis. Bronchoalveolar lavage (BAL) taken from middle lobe was clear, cytological examination of which revealed inflammatory smears, predominantly constituted equally by lymphocytes and alveolar macrophages, $20 \%$ of which were hemosiderin laden macrophages (figure 2). She was diagnosed with tracheal vasculitis with diffuse alveolar haemorrhage $(\mathrm{DAH})$ and managed with pulse intravenous cyclophosphamide with oral corticosteroids, following which, her cough disappeared. She has

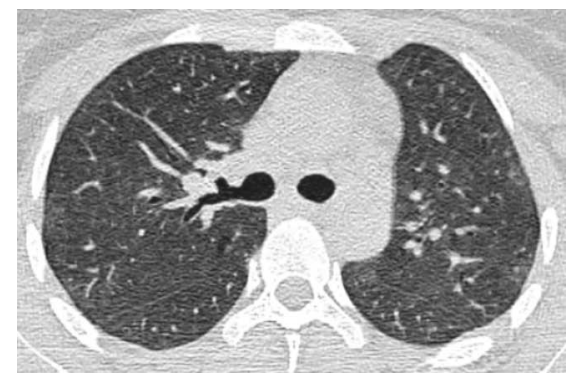

Figure 1 Dark bronchus sign-CT of thorax at the level of right upper lobe bronchus showing diffuse ground glass attenuation of the lung parenchyma discernible when compared with the relatively 'darker' air-filled bronchus.

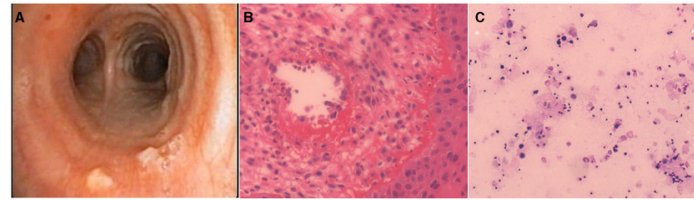

Figure 2 (A) Flexible video bronchoscopy showing necrotic appearing nodules over posterior wall of distal trachea. (B) Tracheal nodule biopsy on H\&E stain showing blood vessel with inflammatory cellular infiltrate predominantly neutrophils and fibrinoid necrosis in the wall (×200 magnification). (C) Bronchoalveolar lavage shows scattered hemosiderin laden macrophages (Perls' Prussian blue), bronchial epithelial cells and lymphocytes (×100 magnification).

received five cycles of cyclophosphamide till date and is doing well.

Classically, DAH commonly, but not necessarily, presents with dyspnoea, haemoptysis with falling blood haematocrit and bilateral lung infiltrates. CT thorax may show patchy involvement, with areas of consolidation or ground glass attenuation. ${ }^{1}$ The latter can be identified when comparing with neighbouring normal lung parenchyma. However, when there is diffuse and uniform ground glass involvement with no 'normal' areas to compare with, one may miss to identify it. Comparison with the neighbouring air-filled bronchus, which will appear relatively darker, may help identify diffuse ground glass attenuation, and hence the aptly named 'dark bronchus sign'. Its importance has been reported in a patient with pulmonary Pneumocystis jirovecii infection. ${ }^{2}$ We believe this is the first case report of this sign in DAH and also believe this sign to be rather non-specific and can be useful in identifying other diseases where uniform ground glass attenuation can occur, as in non-specific interstitial pneumonia (NSIP) and viral or atypical pneumonias.

In the absence of haemoptysis or falling haematocrit and presence of clear BAL return, a diagnosis of

\section{Patient's perspective}

I was earlier informed that I had SLE and was started on oral steroid therapy, but later discontinued fearing long term side effects of therapy. My cough has been disturbing me for a month to the extent that there is never a moment when I am not coughing during the day. After bronchoscopy and pulse cyclophosphamide therapy, I am better and my cough has disappeared. Overall, I also feel better. 


\section{Learning points}

Identifying ground glass attenuation on $\mathrm{CT}$ thorax requires neighbouring normal parenchymal areas for comparison. When ongoing subtle alveolar haemorrhage is involving, all areas of the lung parenchyma uniformly, ground glass attenuation may not be discernible as there is no area of normal parenchyma to compare with. In such cases, we must compare with the air in the airways.

- Diffuse alveolar haemorrhage may at times be so subtle that the classical clinical presentation of haemoptysis, falling haematocrit and bilateral lung infiltrates may not be present altogether in a single patient.

- Serial aliquots of saline should be instilled, and corresponding bronchoalveolar lavage return examined to identify diffuse alveolar haemorrhage, which may be missed when only a single sample is taken.

DAH was not considered earlier. We initially suspected a cellular variant of NSIP and proceeded with bronchoscopy to obtain BAL fluid for cellular composition analysis. In retrospect, on seeing the tracheal nodules, we should have considered instilling serial aliquots of saline and examining the corresponding return during BAL, through which we may have identified DAH. Perhaps, the DAH was so subtle, thus explaining the clear BAL fluid on a single sample. This may also explain why she did not have haemoptysis nor a falling haematocrit. Finally, a diffusing capacity of the lungs for carbon monoxide may have sufficed to identify DAH in this setting. However, once again, we reiterate that $\mathrm{DAH}$ was not considered as a differential diagnosis initially.

Contributors IIA and NM contributed to patient care and manuscript preparation. SS contributed to examination and reporting on pathology specimens and manuscript preparation.

Funding The authors have not declared a specific grant for this research from any funding agency in the public, commercial or not-for-profit sectors.

Competing interests None declared.

Patient consent for publication Obtained.

Provenance and peer review Not commissioned; externally peer reviewed.

\section{REFERENCES}

1 Park MS. Diffuse Alveolar Hemorrhage. Tuberc Respir Dis 2013;74:151-62.

2 Yadav P, Seith A, Sood R. The 'dark bronchus' sign: HRCT diagnosis of Pneumocystis carinii pneumonia. Ann Thorac Med 2007;2:26-7.

Copyright 2019 BMJ Publishing Group. All rights reserved. For permission to reuse any of this content visit

https://www.bmj.com/company/products-services/rights-and-licensing/permissions/

BMJ Case Report Fellows may re-use this article for personal use and teaching without any further permission.

Become a Fellow of BMJ Case Reports today and you can:

- Submit as many cases as you like

- Enjoy fast sympathetic peer review and rapid publication of accepted articles

- Access all the published articles

- Re-use any of the published material for personal use and teaching without further permission

Customer Service

If you have any further queries about your subscription, please contact our customer services team on +44 (0) 2071111105 or via email at support@bmj.com.

Visit casereports.bmj.com for more articles like this and to become a Fellow 